\title{
Belphégor
}

\section{A Companion to the Companions}

\section{Review Essay}

\section{Amy J. Ransom}

\section{(2) OpenEdition}

\section{Journals}

Electronic version

URL: http://journals.openedition.org/belphegor/834

DOI: 10.4000/belphegor.834

ISSN: 1499-7185

Publisher

LPCM

\section{Electronic reference}

Amy J. Ransom, « A Companion to the Companions », Belphégor [Online], 15-1 | 2017, Online since 23 June 2017, connection on 24 September 2020. URL : http://journals.openedition.org/belphegor/834 ; DOI : https://doi.org/10.4000/belphegor.834

This text was automatically generated on 24 September 2020.

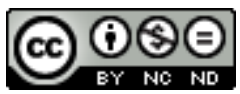

Belphégor est mis à disposition selon les termes de la Licence Creative Commons Attribution - Pas d'Utilisation Commerciale - Pas de Modification 4.0 International. 


\title{
A Companion to the Companions
}

\author{
Review Essay
}

Amy J. Ransom

\section{REFERENCES}

Bould, Mark, Andrew M. Butler, Adam Roberts, and Sherryl Vint, eds. The Routledge Companion to Science Fiction. New York and London : Routledge, 2009. Rpt $2011 ; 2015$. 554 p. ISBN 978-0-415-45379-0

Hubble, Nick, and Aris Mousoutzanis, eds. The Science Fiction Handbook. London :

Bloomsbury, 2013. 265 p. ISBN 978-1-4411-7096-5

James, Edward, and Farah Mendlesohn, eds. The Cambridge Companion to Science Fiction.

London : Cambridge University Press, 2003. 295 p. ISBN 0-521-01657-6

Latham, Rob. ed. The Oxford Handbook of Science Fiction. London : Oxford University Press, 2014. 620 p. ISBN : 978-0-19-983884-4

Seed, David, ed. A Companion to Science Fiction. Oxford : Blackwell, 2008. 612 p. ISBN

978-1-4051-8437-3

Seed, David. Science Fiction : A Very Short Introduction. Oxford : Oxford University Press, 2011. 160 p. ISBN 978-0-19-955745-5

Vint, Sherryl. Science Fiction : A Guide for the Perplexed. London : Bloomsbury, 2014. 210 p. ISBN 978-1-4411-1960-5

1 What is a companion? A companion is someone who is frequently at our side, a fellow traveler with whom we dialogue and share opinions, whose advice we might seek when in doubt. At least that begins to define the nature of a human companion; but what is a "companion" when it is a book? That question, in part, provided the impetus for this review essay on the widening array of introductory and reference books on the sciencefiction genre. For some time, I have been trying to untangle the meaning of the range of terms applied to such publications : companion, handbook, guide(book). ${ }^{1}$ Then, in fall 2015, Routledge announced the republication of their Companion to Science Fiction (originally published in 2009) in electronic format, a "new" release allowing for the pretext of a review. Given the number of publications already competing with it, along 
with a confusing inconsistency in terminology, I propose here a comparative review of similar volumes published in the last decade or so. This list might have been even longer had I included analogous volumes devoted to specific media or sub-genres, such as Sonja Fritzsche's Liverpool Companion to World Science Fiction Film (2014) ${ }^{2}$ and Gerry Canavan and Eric Carl Link's Cambridge Companion to American Science Fiction (2015). As it is, with nearly 3000 pages to chew on, I have an adequate corpus to draw some conclusions and make some recommendations.

2 When handled together physically, it is clear that The Routledge Companion to Science Fiction, A Companion to Science Fiction, and The Oxford Handbook of Science Fiction aspire to the status of complete and definitive reference works on the genre. Published by major academic presses, these hefty tomes reach well over 500 pages each, include dozens of chapters authored by established experts in the field. Indeed, their coverage is so extensive that they all divide their content into several larger "Parts," devoted to broader categories, such as History, Theory, Subgenres, and so on. Although they appear to target the library market, the use of the term "companion" in most of their titles suggests their indispensability for individual experts in the field. The following remarks, I hope, will help you choose your companion wisely.

Before addressing these more recent volumes, I would like to acknowledge the earlier, more modest Cambridge Companion to Science Fiction (CCSF), edited by eminent scholars Edward James and Farah Mendlesohn. Published in 2003, yet still pertinent in many areas, at under 300 pages and $\$ 35$ US dollars, this volume may serve the needs of many students and instructors. Like its larger (and far more expensive) competitors, CCSF covers the history, major sub-genres and themes, as well as key critical approaches to sf ; its contributors are well-known and respected academics, editors, and writers in the field, including Brian Attebery, Damien Broderick, John Clute, Gwyneth Jones, Joan Slonczewski, and Brian Stableford. Its twenty chapters are divided into three parts. Part I, "The History," traces the genre's pre-history in the literary utopia and its development as science fiction (among other terms) through the year 2000 across four chapters. It also includes a chapter on "Film and television" (Mark Bould) and "Science fiction and its editors" (Gary K. Wolfe). Part 2, "Critical Approaches," includes chapters on Marxist (Istvan Csicsery-Ronay, Jr), feminist (Veronica Hollinger), and queer (Wendy Pearson) theories, as well as a chapter on postmodernism and science fiction (Andrew M. Butler). Part 3, "Sub-genres and themes" includes ten chapters on topics such as race and ethnicity (Elisabeth Anne Leonard), religion (Farah Mendlesohn), as well as major sub-genres : hard sf (Kathryn Cramer), space opera (Gary Westfahl), alternate history (Andy Duncan), utopia and anti-utopia (Edward James). The major drawback to a pioneer like CCSF is that a lot has happened both in science-fiction writing and science-fiction studies since the year 2000 ; for anyone studying contemporary sf, clearly a more recent volume will be needed. It is to be hoped that the editors might revise and update the book, adding two chapters to the history section (one each on sf literature and film/tv since 2000), as well as chapters on posthumanism, energy studies, and other recent critical approaches and themes.

4 In terms of currency, the most up-to-date and innovative of these works is clearly Rob Latham's Oxford Handbook of Science Fiction (OHSF), but it remains only available in hardcover (list price \$ 160.00 US) and Kindle editions (list price \$ 103.99 US), with price tags clearly prohibitive for student purchase. Its forty-four chapters, most with one- 
word titles, resemble encyclopedia entries in some ways, yet all are meaty expositions of key elements of the genre ; divided into four parts-"Sf as genre," "Sf as medium," "Sf as culture," and "Sf as worldview"-it seeks not only to define, but also to innovate and expand how we think of the genre. Eschewing a stand-alone section on history, it refuses to limit sf's history to the realm of literature ; indeed, it often reads like a metahistory not of science fiction, but of science fiction studies. This appears clearly in Art Evans' chapter, "Histories," which, rather than re-telling the history of the genre itself, offers a historiographical approach to how its history has been variously constructed by scholars. Not only does the OHSF expand and update our notion of sf by including chapters on "Video Games" (Paweł Frelik), "Theme Parks" (Leonie Cooper), and "Digital Arts and Hypertext" (James Tobias), it identifies the genre's near omnipresence in contemporary culture via chapters on topics like "Body Modification" (Ross Farnell), "Advertising and Design" (Jonathan M. Woodham), and "Pseudoscience" (Anthony Enns). Given the innovative nature of many of these topics' links to sf, in addition to the usual suspects (the book includes chapters by Sherryl Vint, Veronica Hollinger, J. P. Telotte, Roger Luckhurst, Peter Stockwell, Brooks Landon, and other eminent figures in the field), scholars less familiar to the sf academic community have contributed, but they are also senior scholars in their respective fields. Make no mistake, although this may not be your father's science fiction, this significant volume includes important interventions on topics more traditionally linked to the genre's development, such as "The Enlightenment" (Adam Roberts'), "The Gothic" (William Hughes), "Darwinism" (Patrick B. Sharp), and "Atomic Culture and the Space Race" (David Seed). My only complaints about this book are its exorbitant price and Oxford's choice of the term handbook rather than companion, for this book is clearly most similar to the other socalled companions reviewed here. It will sit in a handy location near my desk and be consulted frequently, I imagine.

5 In many ways, The Routledge Companion to Science Fiction (RCSF) is as ambitious as the OHSF, also seeking to expand the scope of the genre and to reflect its hegemonic presence in contemporary culture. Plus, it is now available in a relatively affordable paperback (\$54.95 US) and electronic formats; its availability via an on-line institutional platform (Routledge Handbooks Online) may make this an excellent option for college and university libraries, allowing students ready access as they research at home. In addition to being edited by some of the most respected figures in sf scholarship today, its contributors list frequently overlaps those of the other volumes reviewed here; in addition to senior scholars like Adam Roberts, Arthur B. Evans, Brooks Landon, Rob Latham, Joan Gordon, and Jane Donawerth, it includes work by dynamic mid-career academics like Lisa Yaszek, Isiah Lavender III, Matt Hills, and Graham J. Murphy.

6 Its fifty-six chapters are divided into four, more traditional parts than OHSF. Thus, Part I, "History," surveys the range of the genre's development in print and the visual media ; however, its subdivision into eighteen chapters allows for contributors to cover briefer periods of time than in similar books. This section also innovates, including chapters on "Sf tourism" (Brooks Landon), "Manga and anime" (Sharalyn Orbaugh), and three more chapters on Anglo-American comics (Marek Wasielewski ; Jim Casey; Abraham Kawa). Adam Roberts' discussion of the genre's origins in "The Copernican Revolution" is masterful, but one gap in the chronology appears in the lack of coverage of the seventeenth century. Part II, "Theory" includes fourteen separate chapters on such critical approaches as "Postcolonialism" (Michelle Reid), "Nuclear criticism" (Paul 
Williams), and "Fan studies" (Robin Anne Reid). It evidences fewer gaps here, but lacks coverage of the rising areas of Indigenous futurism and energy studies. Whereas a number of expected topics appear in Parts III, "Issues and Challenges," and IV, "Subgenres," there are also some refreshing approaches to these such as "Design for screen sf" (Piers D. Britton) and separate discussions of "Arthouse sf film" and "Blockbuster sf film," although both are by the same author (Stacey Abbott). A real highlight is China Miéville's contribution on "Weird fiction." Like the CCSF, however, RCSF suffers particularly in its lack of coverage of exciting developments, particularly in science-fiction television, since its original publication in 2008 and thus requires updating prior to any future editions.

7 David Seed's edited volume, the somewhat more humbly named A Companion to Science Fiction (ACSF) (rather than The...), offers a useful element not found in the three companions discussed so far: chapters covering major authors and readings of key works. This might be a deciding factor for some buyers; it is also available in paperback, around $\$ 60$ US. Similar in length to both the RCSF and the OHSF, it offers forty-one chapters, authored by many scholars already mentioned above, as well as by some established names unrepresented elsewhere. Particularly noteworthy are Japanese scholar Takayuki Tatsumi's "Japanese and Asian Science Fiction," Carl Freedman's study of "Samuel Delany: A Biographical and Critical Overview," and Warren G. Rochelle's chapter on "Ursula K. Le Guin." ACSF offers the widest variety of sub-divisions, with seven different parts. Parts I, "Surveying the Field ;" II, "Topics and Debates ;" and III, "Genres and Movements," largely reproduce categories seen already. However, individual chapters offer some variation and re-organization of material. Tom Shippey's "Hard Reading: The Challenges of Science Fiction" and Brian Stableford's "Science Fiction and Ecology," for example take approaches to the genre not found elsewhere. Topics already seen like, "The Origins of Science Fiction" and "Utopia" are prepared respectively by important names not recruited by the other volumes' editors, the late George Slusser and Phillip E. Wegner respectively.

8 Science Fiction Film is given its own section in Part IV of ACSF, with less systematic coverage ; sf film pioneer Vivian Sobchack authors "American Science Fiction Film : an Overview," while Christine Cornea takes a thematic approach in "Figurations of the Cyborg in Contemporary Science Fiction Novels." Fans of Doctor Who will not want to miss Peter Wright's "British Science Fiction Television." Part V, "The International Scene," is rather disappointing, given that two of its three chapters cover regions within the "Anglo-American" umbrella, broadly defined: Canadia (Douglas Barbour), Australia (Van Ikin and Sean McMullen), and the aforementioned chapter on Japan by Tatsumi.

Setting ACSF apart from its competition are Parts VI and VII, "Key Writers" and "Readings," which may be most useful to teachers and students as they offer more indepth coverage of single authors and texts. These nineteen chapters, nearly half of the book, present a range of significant Anglo-American works and writers from all periods; in addition to Delany and Le Guin (mentioned above), they include Wells (Robert Crossley), Asimov (John Clute), Wyndham (David Ketterer), Dick (Christopher Palmer), Gwyneth Jones (Andy Sawyer), Clarke (Edward James), Egan (Russell Blackford), Frankenstein (Susan E. Lederer and Richard M. Ratzan), Herland (Jill Rudd), Brave New World (David Seed), Fahrenheit 451 (Brian Baker), The Female Man (Jeanne Cortiel), Crash (Roger Luckhurst), The Handmaid's Tale (Faye Hammill), Neuromancer 
(Andrew M. Butler), Robinson's Mars Trilogy (Carol Franko) and Banks' Excession (Farah Mendlesohn). Whereas the choice of topics covered in some parts of the book sometimes seems a bit random (editors even of such well-organized volumes may be somewhat at the mercy of their contributors' interests), this last section appears to have been brilliantly thought through, including signal works from different periods. Even if it was mere serendipity, the corpus of authors and texts assembled here would provide an excellent framework for an introductory course on Anglo-American sf.

10 Collectively these works outline the genre's histories, in literature and other media, reveal critical priorities, and suggest future avenues of study in sf. Perhaps surprisingly, given the genre's traditional identification as a "male" genre, all four volumes address feminist contributions to its criticism, literature, or both. The only other area covered in all four volumes is utopia/dystopia; race and sf, nuclear/atopic criticism, and the sub-genre of hard sf appear in three of the four works. Overall, apart from only one or two exceptions in what amounts to some 150 total chapters, the quality of the writing and scholarship is excellent; for the most part, a relatively uniform story for the genre is told. As might be expected, the Anglo-American canon is heavily privileged in the way that story is told. With the exception of contributions by Art Evans, Adam Roberts, and Brian Stableford on early sf, there is little mention of what Andrew Milner has begun to call the "Anglo-French origins" of the genre. ${ }^{3}$ Indeed, apart from passing nods to Asian contributions, readers interested in global sf will have to wait for additional scholarship. ${ }^{4}$ The same flaw appears in the final three works to be reviewed here, although Seed's Very Short Introduction openly acknowledges that "this volume will focus on Anglophone writing" (4).

11 A very different beast from The Oxford Handbook, The Science Fiction Handbook (SFHB), edited by less well-known figures in the field Nick Hubble and Aris Mousoutzanis, was published in Bloomsbury's series of "Literature and Culture Handbooks." SFHB most clearly proposes to serve as a course text for undergraduates. Its eleven chapters are divided with clear intertitles to guide the reader, and it includes reference-type sections with paragraph-length entries on "Key Critical Concepts, Topics and Critics" (David M. Higgins and Roby Duncan), along with some more essay-style chapters. Above all, the two chapters titled "Case Studies in Readings" one each for "Key Primary Literary Texts" (Christopher Daley) and "Key theoretical and Critical Texts" (Jessica Langer), clearly suggest the book's pedagogical bent. With several chapters authored by young scholars, this book is clearly of the least interest to the advanced sf scholar.

12 It still remains unclear to me how a handbook differs from a companion, or even a guide; particularly since Sherryl Vint's solo-authored, Science Fiction: A Guide for the Perplexed (SFGP), part of the same publisher's "Guides for the Perplexed" series, covers very similar topics to those already addressed in other works. These Bloomsbury titles are a far more modest, both in size and in price point ; they might work as companion texts for a course on sf, for that matter. Their popular approach suggests a slightly different audience than the advanced scholar; that said, Vint's name on the cover of SFGP lends it a certain weight. And while chapter one's title, "What is Science Fiction?" suggests a very basic familiarity with the genre, this is by no means a "sf for Dummies" volume. Already in chapter one, she engages such concepts as the sublime and by chapters three and four, Vint is taking her readers on a tour of significant critical concepts like Suvin's "Cognitive Estrangement" and the sf "Megatext." This serious introduction would actually serve graduate students and junior faculty who have 
decided to embark on the study of sf, providing an excellent framework for more advanced reading.

The better choice for the general audience is David Seed's Science Fiction : A Very Short

Introduction (SFVSI), which appears in Oxford University Press's very long line of very short introductions. His introduction makes clear that Seed "cannot offer a history of SF [...]. Instead, it will attempt to tie the selected examples to their different historical moments to demonstrate how science fiction has always been an evolving mode" (2). Seed nonetheless takes a very historical approach throughout the handsome little volume, providing many examples of early and nineteenth-century sf, with largely descriptive, rather than analytical synopses, as well as some nice illustrations. The volume's chapters are organized thematically, as follows : 1) "Voyages into Space ;" 2) "Alien Encounters ;" 3) "Science Fiction and Technology ;" 4) "Utopias and Dystopias ;" 5) "Fictions of Time ;" with an additional chapter on 6) "The Field of Science Fiction." The latter offers brief discussions of the notion of genre, sf criticism, media, and the role of magazines and fandom. With critical terms like "cognitive estrangement" and "feminism" only lightly peppered throughout the volume, this is actually a better guide for the perplexed.

14 What conclusions can be drawn from this admittedly very rapid overview? My recommendations would vary by audience and purchaser. Libraries should be instructed to purchase at least one of the major works, either the OHSF, RCSF, or ACSF. Because David Seed recruited a quite different body of contributors, I would recommend that larger libraries should acquire (if they haven't already) Seed and either Latham (OHSF) or Bould et al. (RCSF) since the two latter texts involve a significant amount of overlap. Individuals with a serious scholarly interest in sf, including instructors developing a first course on the genre, may want to invest in their own copy of James and Mendlesohn (CCSF), which is both affordable and portable. Specialists in the field might nonetheless want to purchase copies of Seed's Very Short Intro or Vint's Guide to the Perplexed for family members who simply do not "get" what we do! Finally, as already suggested, Hubble and Mousoutzanis should be reserved as an undergraduate course text, but also possibly as a quick reference guide to be acquired by libraries.

15 My final conclusion: you can't judge a book by its title. Whereas there is some consistency in the concept that a companion is a scholarly introduction to a field or genre, the nature of the handbook remains elusive based on the vast difference between the two works sampled here. What is clear from this proliferation of reference works is that sf as a genre has certainly "arrived" as a serious object of academic study and its hegemony into all aspects of human life is made undeniable by the wide array of interfaces covered in these works. 


\section{NOTES}

1. See my forthcoming review essay of two very different "handbooks" (Latham; Hubble and Mousoutzanis) in Journal of the Fantastic in the Arts, vol. 27 (2016) for a more complete discussion of those two volumes.

2. See my review of this volume in SFRA Review 311 (Winter 2015).

3. Andrew Milner, Locating Science Fiction, Liverpool: Liverpool UP, 2012, p. 156; 165.

4. This is, however, the new trend. Not only does Dale Knickerbocker have an edited volume on master writers of global sf forthcoming from University of Indiana Press, several presses have initiated series soliciting studies in English of non-Anglo-American science fiction.

\section{AUTHOR}

\section{AMY J. RANSOM}

Central Michigan University 